\title{
Járvány, vírus, Virológiai Nemzeti Laboratórium
}

\author{
Jakab Ferenc \\ Pécsi Tudományegyetem, Szentágothai János Kutatóközpont, Virológiai Nemzeti Laboratórium, Pécs, Magyarország \\ Pécsi Tudományegyetem, Természettudományi Kar, Biológiai Intézet, Pécs, Magyarország \\ Beérkezett: 2021. 05. 17.; Elfogadva: 2021. 06. 10.
}

\begin{abstract}
Összefoglalás
A fertőző betegségek világméretú fenyegetettsége és terjedése komoly társadalmi, egészségügyi kockázatot jelent minden nemzet számára. A lokális problémák megoldása mellett minden esetben közös nemzeti és nemzetközi összefogás szükséges. Az elmúlt években hazánkban is egyre nagyobb számban jelentek, illetve erősödtek meg új fertôző betegségek, amelyek szignifikáns társadalmi fenyegetést jelentenek. Éppen ezért a Virológiai Nemzeti Laboratórium (VNL) létrehozásának célja a Pécsi Tudományegyetem, Szentágothai János Kutatóközpont (PTE SzKK) kötelékén belül múködő komplex virológiai laboratóriumi egység kutatási teljesítményének és kutatás-fejlesztési tevékenységének növelése, és ezzel párhuzamosan részvétel a hazai és nemzetközi szintú kutatási hálózatok munkájában. A VNL-hez tartozó komplex virológiai kutatási egység egyedüli hazánkban, hiszen minden biológiai biztonsági szintú laboratóriumi facilitással rendelkezik. Ennek megfelelóen lehetőség van a 2-es (BSL-2), 3-as (BSL-3) és egyetlen egyetemi fenntartású laboratóriumként 4-es biológiai biztonsági szintű (BSL-4) laboratóriumi tevékenység elvégzésére. Ezzel egyedülálló lehetőséget nyit hazánkban is a fertőző betegségek leküzdésében vívott harcban. Hazánkban a PTE rendelkezik az egyetlen ilyen komplex virológiai kutatólaboratóriummal, amelyet tisztán kutatási és nem járványügyi feladatok elvégzésére hoztak létre. Ennek megfelelően az itt munkát végző fiatal kollégák az egyetemi prioritásoknak megfelelóen a nemzetközileg elismert, kimagasló tudományos eredmények elérését túzték ki célul. Mivel a laboratóriumi egység egyedülálló hazánkban, így a virológia területén nemcsak a kutatást, de az oktatást is kiválóan szolgálja.

A PTE SzKK Virológia Kutatócsoportjának elsődleges kutatási területe az állatokról emberekre terjedő, úgynevezett virális zoonózisok vizsgálata. Ezen kórokozók a legtöbb esetben súlyos, akár halálos kimenetelú fertôzéseket is képesek okozni, éppen ezért a vizsgálatok igen magas szakmai kompetenciát és megfelelő laboratóriumi infrastruktúrát igényelnek. Mindazonáltal az ilyen irányú vizsgálatok száma nemzetközi szinten is igen megnőtt, hiszen az új betegségek megjelenése is gyakoribbá vált, amit elsősorban a környezeti és emberi tényező́k együttes hatása eredményezhet. A kutatócsoport az alapkutatásokon kívül számos alkalmazott kutatási projektben is részt vesz, amelyek célja a humán diagnosztikában, betegellátási gyakorlatban is alkalmazható tesztek, potenciálisan antivirális hatóanyagok fejlesztése, tesztelése. Mivel a laboratórium egyedülálló biológiai biztonsági szinttel rendelkezik az ilyen irányú alkalmazott kutatásokban, kutatás-fejlesztési és innovációs $(\mathrm{K}+\mathrm{F}+\mathrm{I})$ tevékenységekben is részt tud venni, ezzel emelve a hazai kutatás-fejlesztési irányokat a mikrobiológia területén. A virológiai laboratórium nemcsak alap- és alkalmazott kutatásokat folytat, de szükség esetén részt tud venni a hazai védelmi, biztonsági szervek munkájában is.

A VNL fó célja egy hazai, magas színvonalú nemzeti virológiai kutatási centrum létrehozása, amely elősegíti a hazai virológiai kutatások tudományos fejlesztését, valamint a szakterület $\mathrm{K}+\mathrm{F}+\mathrm{I}$ tevékenységének növelését.
\end{abstract}

Kulcsszavak: vírusok, virológia, Virológiai Nemzeti Laboratórium, járvány, kutatás

\section{Epidemic, virus, National Laboratory of Virology}

Ferenc Jakab

National Laboratory of Virology, Szentágothai Research Centre, University of Pécs, Pécs, Hungary Institute of Biology, Faculty of Sciences, University of Pécs, Pécs, Hungary

\section{Summary}

Today, the global threat and spread of infectious diseases pose serious social and health risks for every nation of the world. In addition to local challenges, there is a sustained need for national and international collaborations. In recent years, numerous new infectious diseases have emerged and grown into significant social threats also in Hungary. 
Therefore, in collaboration with national and international research networks, the ultimate goal of the National Laboratory of Virology (NLV) is to boost the performance and R\&D activities of the Virology Laboratory complex of the Szentágothai János Research Centre (PTE-SzKK) at the University of Pécs. Due to its specific, high level facilities, our virology research unit has a unique asset in Hungary. Accordingly, it is capable of conducting experiments requiring Biosafety Level 2 (BSL-2), Biosafety Level 3 (BSL-3) and as the only academically supported unit in Hungary, it is also capable of covering Biosafety Level 4 (BSL-4) standards to uniquely combat infectious diseases in the area. Our laboratory is a distinctive research facility not only nationally, but internationally as well. Currently, the University of Pécs possesses the only virological research laboratory in Hungary that was established purely for research purposes and not for performing epidemiological tasks. Accordingly, aligned with their academic priorities, our young investigators set their horizons towards achieving internationally recognized, outstanding scientific results. Notably, because our renowned laboratory unit is unparalleled throughout the country, colleagues are wishing to pursue research and training in the field of virology

The primary research field of the PTE-SzKK Virology Research Group is studying the so-called viral zoonoses; infectious transmissions from animals to humans. In most cases, these pathogens may cause serious, or even fatal infections requiring high level professional competence and corresponding laboratory infrastructure. Nevertheless, the number of international studies has recently surged as new diseases evolve and become more common due to the combined effects of environmental and human factors. In addition to basic science, our team is also conducting a number of applied research projects such as development of potential antiviral agents and tests for human diagnostics and medical care. Since our laboratory possesses a particularly high level of biosafety, it may be equally utilized in clinical practice and by providing novel directions for the national microbiology research and R\&D field. Moreover, NLV not only implements basic and applied research, but also collaborates with various organizations of the Homeland Security of Hungary.

The primary goal to establish an NLV was to utilize a National research facility in the field of virology in Hungary in order to increase both research and R\&D activity in the country.

Keywords: viruses, virology, National Laboratory of Virology, edipemic, research

\section{Miért pont most?}

A fertőző betegségek világméretű fenyegetettsége és terjedése komoly társadalmi, egészségügyi kockázatot jelent minden nemzet számára. A lokális problémák megoldása mellett minden esetben közös nemzeti és nemzetközi összefogás szükséges. Az elmúlt években hazánkban is egyre nagyobb számban jelentek, illetve erősödtek meg új fertőző betegségek, amelyek szignifikáns társadalmi fenyegetést jelentenek. A globalizáció és a felgyorsult migráció miatt napjainkban a fertőző betegségek egyre jelentősebb térhódítása figyelhető meg szerte a világon. A kórokozók nagymértékú terjedésének hátterében számos faktort leírtak már, de a tények azt bizonyítják, hogy az emberi civilizáció terjedésével, a modern kor technológiai találmányai és az életminőség javítása érdekében bevezetett vívmányok előnyei sokszor számos veszélyt is rejthetnek magukban. Az emberi mobilitás felgyorsulása a fertőző betegségek számára határtalan, emberi erővel szinte megállíthatatlan lehetőségeket biztosít újabb és újabb járványok kialakulására.

A WHO 2015-ben kelt tanulmánya azt mutatta, hogy az egész világon bekövetkezett 56,4 millió haláleset közel 20\%-át okozták fertőző betegségek, az összes WHOrégióban a fertőző betegségek jelentik az öt évnél fiatalabb gyermekek halálozásának vezető okát.

Az elmúlt időszak nagy járványai (Zika-vírus, Ebola), de különösen a jelenleg pusztító SASR-CoV-2 világjárvány rávilágított a fertőző betegségek fenyegetésére és a velük szembeni világméretû sebezhetőségre. A járványok megelőzéséhez és az ezekre való reagáláshoz összehangolt és azonnali cselekvésre van szükség, melyet elsősor- ban a magas biológiai biztonsági szintû́ laboratóriumok kutatási kapacitásainak egyidejú múködése tudja megvalósítani. A virológiai kutatások célja szerte a világon az, hogy hozzájáruljanak az emberi egészség védelmének átfogó küldetéséhez azáltal, hogy növelik felkészültségét és képességét a fennálló súlyos következményekkel járó fertőző betegség vagy az újonnan kialakult fertôző betegség fenyegetésére (Wu et al. 2017; Marano-ArguinPappaioanou 2007).

Számos olyan tényezőt tudunk azonosítani, melyek felelősek az új fertőző betegségek megjelenéséért, illetve régebbi megbetegedések újbóli megjelenéséért:

- Globalizáció, utazás és migráció: a globalizáció eredményeként megnövekedett az olyan kórokozók globális expozíciója, amelyek korábban csak kis, endemikus vagy távoli területekre korlátozódtak.

- Növekvő népesség, erôsödő urbanizáció és zsúfolt nagyvárosok.

- Klímaváltozás: a Föld éghajlatának melegedésével és az élőhelyek megváltozásával a betegségek új földrajzi területeken terjednek.

- Nagyobb kölcsönhatás az emberek és a gazdaállatok között: ahogy egyre több erdő́t vágnak ki a városi települések számára, a betegséget terjesztő állatok egyre közelebb kerülnek az emberekhez.

A fertőző betegségek (kezelés, oltások és diagnosztika) globális piacát 2016-ban 59,7 milliárd dollárra becsülték, amely 2022-re várhatóan körülbelül 99 milliárd dollárra növekszik, a piac éves bővülése közel 9\%-os értékú. A piac legjelentősebb részét, közel $75 \%$-át adják terápiás szerek. 
Az újonnan megjelenő virális fertőzések jelentős része állati eredetű, úgynevezett zoonótikus (virális zoonózis) betegség lehet. A fertőző betegségek legyőzése érdekében nagyon fontos, hogy megértsük a betegség terjedésének módját. A fertőző ágensek gyakran „gazdaállatokban" találhatók, és terjesztésükben több út is lehetséges (Morens-Folkers-Fauci, 2004):

- Kontakt érintkezés: Ide tartozik a személyes kapcsolat vagy a közvetlen kapcsolat fizikai interakción keresztül a gazdaállattal. A közvetett érintkezés olyan tárgyakat foglal magában, amelyek betegséget okozó kórokozókkal szennyeződnek, és ezeket az új gazdaszervezetre továbbítják.

- Vektoros átvitel: Olyan mechanikus vektort (például házi légy) von be, amely a kórokozót egyik gazdaszervezetről a másikra hordozza anélkül, hogy önmagában megfertőződne, vagy olyan biológiai vektorral (például szúnyog), amely egyben a fertőző ágensek gazdaszervezetét is szolgálja, és megkönnyíti a kórokozók életciklusát.

A globalizált világban nincs lokális probléma! A tudomány és technológia fejlődése határtalan lehetőségeket adott az emberiség számára, amely ugyan felbecsülhetetlen előnyökkel jár, de legalább ugyanilyen mértékben rejti a veszély lehetőségét is. Ha belegondolunk, hogy kicsivel több mint három nap alatt (72 óra) körberepülhetjük a Földet, nem nehéz elképzelni, hogy a fertőző betegségek terjedése szinte megállíthatatlanná válhat. Erre számos példát mutatott már a természet, például a 2001-2002-ben megjelent SARS koronavírus-járvány, az új típusú $\mathrm{H} 1 \mathrm{Nl}$-influenzavírus, vagy akár az elmúlt években hatalmas port kevert nyugat-afrikai Ebola-járvány. Természetesen „iskolapéldája” a pandémiák kialakulásának a mostani SARS-CoV-2 világjárvány is. Így talán mindenki számára egyértelmű, hogy a fertőző betegségek ellen vívott harc csak és kizárólag tudományterületi összefogással valósulhat meg! A zoonótikus fertőzések kutatása, diagnosztikája különösen nagy kockázattal jár, így a laboratóriumi vizsgálatokhoz magas szintú biológiai biztonsági laboratóriumok (BSL) szükségesek. A környező európai országokban az elmúlt években jelentősen növekedett a virális zoonózisokkal foglalkozó kutatócsoportok száma és aktivitása. Nemzeti, illetve több országot összefogó nemzetközi kutatási hálózatok is létesültek, elsősorban a betegségek felderítésére és diagnosztikai fejlesztésekre. Ennek megfelelően a hagyományos mikrobiológiai/virológiai laboratóriumok nem képesek megfelelően biztonságos körülmények között a kórokozókkal dolgozni, fontos a speciális BSL laboratóriumok megléte, legalább régiós szinten (van Doorn, 2014).

A biológiai biztonsági laboratóriumok jelenleg 4 csoportba sorolhatók (BSL-1-4), melyek közül a legmagasabb BSL-4 kategóriába kizárólag súlyos, életveszélyes fertőzéseket okozó vírusok tartoznak, amelyek ellen sem célzott terápia, sem védőoltás nem áll rendelkezésre.
Európában jelenleg több BSL-4 laboratórium múködik, amelyek közül (legjobb tudásunk szerint) mindössze 3 laboratórium tartozik egyetemi kötelékbe és végez tényleges alap- és alkalmazott kutatásokat. A többi laboratórium elsősorban állami járványügyi, diagnosztikai laboratórium, állategészségügyi laboratórium vagy profitorientált és katonai laboratóriumi egység. Látható tehát, hogy a BSL-4 kutatólaboratóriumok száma Európaszerte kevés, így ezek a laboratóriumok minden esetben szoros együttmúködésben, közvetlen kooperációban dolgoznak.

\section{Miért a PTE kötelékében?}

A Virológiai Nemzeti Laboratórium egyik fő célja a Pécsi Tudományegyetem (PTE) kötelékén belül múködő magas biológiai biztonsági szintű virológiai laboratórium hazai és nemzetközi kutatási tevékenységének megerősítése. Az érintett laboratórium egyedüli egyetemi BSL-4 laboratórium, amelyet tisztán kutatási és nem járványügyi feladatok elvégzésére hoztak létre, így egyedülálló lehetőséget nyit hazánkban is a fertőző betegségek leküzdésében vívott harcban.

\section{Pécsi Tudományegyetem}

A Pécsi Tudományegyetem (PTE) nemcsak Pécs, hanem a Dél-Dunántúl regionális egyeteme is. A legnagyobb munkáltató a városban, meghatározó szerepe van a régió minden szellemi területén, múvészetekben, tudományban, gyógyításban egyaránt. A nemzetközi és hazai kutatáspolitikai célkitűzéseknek megfelelően, valamint a Déldunántúli régió adottságaihoz igazodva, a PTE olyan nagy potenciállal rendelkező tudományterületekre kívánja koncentrálni szellemi, infrastrukturális és pénzügyi kapacitásait, amelyek képesek lehetnek a régió tudásalapú, innovációorientált gazdaságfejlesztési stratégiáját szolgálni.

A pécsi egyetem rendelkezik a régió legjelentősebb kutatás-fejlesztési célú infrastrukturális kapacitásával, amely több, megközelítóleg $20000 \mathrm{~m}^{2}$ kutatási labor szintterületen helyezkedik el. A kutatás infrastrukturális ellátásában kiemelt jelentőségű lépés, hogy 2012 nyarán átadásra került a PTE Szentágothai János Kutatóközpont.

A PTE 20000 fös hallgatói létszámával, 1600 oktatójával, kutatójával és 10 karával Magyarország egyik legnagyobb felsőoktatási intézménye. Egészen 1367-ig visszanyúló gyökereivel hazánk első egyeteme. Mindeközben az ország egyik legjelentősebb kutatóegyeteme, hatalmas szakmai kutatói bázissal. Az egyetemi karokon 22 doktori iskola múködik, melyek a tudomány és a müvészetek széles spektrumát ölelik fel. A PTE fontos szerepet tulajdonít a tehetséggondozásnak. A szakkollégiumok és tudományos diákkörök célja a diákok tudományos munkájának támogatása. 
A PTE Klinikai Központja Magyarország egyik legnagyobb egészségügyi szolgáltatója. 29 betegellátó egységével, közel 3000 munkatársával több évtizede nyújt egészségügyi ellátást Pécs város, Baranya megye és a régió lakossága részére, emellett aktív részese az orvostanhallgatók és az egészségügyi szakemberek gyakorlati oktatásának. A magas színvonalú tudást ötvözi a modern egészségügyi módszerekkel.

\section{Pécsi Tudományegyetem Szentágothai János Kutatóközpont (PTE SzKK)}

Az SzKK a PTE tudományos zászlóshajója és kiválósági központja, amely a kutatásfejlesztési és innovációs tevékenységek számára egyedülálló kutatói szakmai közösséget, magas színvonalú, modern müszer- és tudáshátteret, valamint korszerú laboratóriumokat biztosít. A kutatóközpont több mint $7000 \mathrm{~m}^{2}$-es területével szolgált a PTE természettudományos, orvosi és müszaki kiemelt kutatási és oktatási tevékenységét.

Célja az orvos-biológiai, természettudományi, múszaki-informatikai kutatások fejlesztése, a tudományos profilok gazdasági és társadalmi igényekhez való közelítése, hazai és nemzetközi együttmúködések előmozdítása, hálózatok építése és széles körû szolgáltatások biztosítása.

A Kutatóközpontban jelenleg 20 kutatócsoport több mint 200 kutatója dolgozik, kiemelt céljuk a nemzetközileg elismert magas színvonalú publikációs aktivitás, az ipari kapcsolatok erősítése, pályázati aktivitás és a versenyképesség növelése a nemzetközi mezőnyben is, fiatal kutatók intenzív bevonása, aktív részvétel graduális és posztgraduális képzésben, utánpótlás-nevelésében.

A kutatási infrastruktúra hatékony múködtetése és fejlesztése érdekében központi kiszolgáló laboratóriumok és egységek kerültek kialakításra, melyek jelentős tudományos és innovációs potenciált, valamint kollaborációs lehetőséget rejtenek magukban. Ezek mentén a kutatási hálózatokba való bekapcsolódás, a pályázati aktivitás erősödik.

\section{PTE SzKK Virológiai Kutatócsoport}

Kutatócsoportunk fó profilja a virális zoonózisok kutatása. Kutatásaink egyik célja ismert és új kórokozók kimutatása hazánkból és külföldről származó mintákból (kiterjedt nemzetközi kollaborációs hálózat révén); gyakoriságuk felmérése, genetikai állományuk részletes jellemzése, valamint a vírusfertőzés mechanizmusának pontosabb megismerése. Kutatásaink során elsősorban a rágcsáló- és denevérpopulációkat vizsgáljuk, de komoly hangsúlyt fordítunk a szúnyog, kullancs és egyéb ízeltlábú vektorok vizsgálatára is. Másik fó célunk a gyakorlati orvostudományt is segíteni, hogy kellő erôvel tudja felvenni a harcot a különböző új és újra fertőző betegségekkel szemben. Ennek megfelelően nagyon nagy hangsúlyt fektetünk vizsgálataink során a potenciálisan új antivirális szerek felderítésére, tesztelésére, valamint részt kívánunk venni a vakcinafejlesztési projektek laboratóriumi fázisaiban is. Mivel a laboratórium egyedülálló biológiai biztonsági szinttel rendelkezik, az ilyen irányú alkalmazott kutatásokban is részt tudunk venni, ezzel emelve a hazai kutatás-fejlesztési irányokat a mikrobiológia területén. Laboratóriumunk nemcsak alap- és alkalmazott kutatásokat folytat, de részt vesz a hazai védelmi, biztonsági szervek munkájában is, valamint elkötelezett a $\mathrm{K}+\mathrm{F}+\mathrm{I}$ tevékenység irányába történő nyitásra egyaránt.

A csoporthoz tartozó BSL-4-es kutatólaboratórium páratlan lehetőséget biztosít a hazai, de nemzetközi szintû projektek lebonyolításához. A csoport emellett rendelkezik egy komplex virológiai kutatási egységgel is, hiszen (a BSL-4 mellett) minden biológiai biztonsági szintű laboratóriumi facilitás is megtalálható egy helyen. Ennek megfelelően lehetőségünk van továbbá a 2-es (BSL-2) és a 3-as (BSL-3) biológiai biztonsági szintû laboratóriumi tevékenységek elvégzésére egyaránt.

A kutatóközpont kiemelt biztonsági épületében helyezkedik el a BSL-4 laboratórium. A laboratórium megfelel az Amerikai Egyesült Államok (USA) Járványügyi és Betegségmegelőzési Központ (CDC) által támasztott nemzetközi kívánalmaknak (BMBL $5^{\text {th }}$ Edition). Számos egyedi építészeti, gépészeti és labortechnológiai rendszerrel rendelkezik a laboratórium, amely kizárólag a legmagasabb biztonsági szintû egységekben található meg. Ilyen például: a hermetikusan záródó elektromágnessel ellátott acélajtók, dupla (130 Pa) negatív nyomás a laboratórium területén, zsiliprendszerü beléptetés, dupla HEPA-filteres levegőszürés, izolált laboratóriumi terület, dekontamináló helyiség, átadó autokláv, egyedi dekontamináló zuhany stb. A laboratórium hivatalos BSL és MEBIR minősítéssel rendelkezik. A biztonsági laboratóriumon kívül a kutatócsoport rendelkezik még hozzávetólegesen $200 \mathrm{~m}^{2}$ általános mikrobiológiai és molekuláris biológiai laboratóriumi területtel.

A kutatás mellett részt veszünk a hazai kutatóképzésben, a kutatói utánpótlás nevelésében is. Biobiztonsági, biovédelmi kurzusokon, tréningeken oktatjuk a hallgatókat, akik az elméleti tudás mellett gyakorlati képzésben is részesülnek. Az oktatásban részt vevő kollégák minden biológiai biztonsági szintû́ munkára fel tudják készíteni a munkatársakat - legyen az akár BSL-2, BSL-3 és BSL-4 szint -, hiszen rendelkezünk egy egyedülálló BSL-4 tréninglaboratóriummal is, ami mindenben megegyezik a tényleges fertőző területen történő munkavégzés feltételeivel.

\section{A Virológiai Nemzeti Laboratórium koncepció}

Az elmúlt időszak nagy járványai (COVID-19, Zikavírus, Ebola) rávilágítottak a fertőző betegségek fenyegetésére és a velük szembeni világméretû́ sebezhetóségre. A járványok megelőzéséhez és az ezekre való reagáláshoz magas biológiai biztonsági szintû laborató- 
riumi kutatási kapacitásra, az érintett szereplők szoros együttmúködésére és tervezett programra van szükség. A kutatók célja egy olyan belső, hazai hálózat kiépítése, amely összefogná a magas fertőzőképességú vírusok kutatásához kapcsolódó tudományterületeket és a legfontosabb hazai és nemzetközi ipari szereplőket.

A Virológiai Nemzeti Laboratórium (VNL) elsődleges célja, hogy a meglévő, kiemelkedő virológiai laboratóriumi facilitásra építve széles spektrumú alap- és alkalmazott kutatási kísérleteket végezzen. Ezek részben az új, felbukkanó fertőző betegségek felderítését, illetve ezek és a már ismert virális fertőzések mechanizmusának jobb megismerését, megértését és ennek következtében az ellenük való védekezések hatékonyabb módjának kifejlesztését célozzák meg. A kísérletek elsősorban a magas fertőzőképességú vírusok okozta virális patomechanizmus vizsgálatok köré épülnek, amelyek a vírusok genomi szintû elemzésétől kezdődően a vírusfertőzés sejtszintü mechanizmusán át egészen az antivirális terápiák fejlesztéséig tartanak. Ez utóbbi nagyon fontos, hiszen az egyik legnagyobb kihívás a hatékony vírusellenes kezelés kifejlesztése vagy a vírusreplikáció gátlásának bármely szintü mechanizmusainak felderítése, hogy időben és hatékonyan tudjunk védekezni az újonnan felbukkanó fertőző betegségekkel szemben. $\mathrm{Az}$ alapkutatás mellett az oktatás és az utánpótlás-nevelés is kiemelt cél. A VNL kutatási koncepciója három, egymással szoros összefüggésben álló pillérre épül.

\section{I. Új, felbukkanó fertőző betegségek felderítése}

A felbukkanó fertőző betegségek rendkívül komoly és komplex kihívást jelentenek az emberiség, de főként a globalizált világrend és a gazdaság számára. Az elmúlt évtizedek során több járvány is megjelent az emberi populációban, számos esetben vadállatok közvetítésével. Az így megjelent kórokozók kétharmad része származik vadállatokból. Markáns példa a jelenleg is világjárványként tomboló SARS-CoV-2 koronavírus, amely egy egyelőre ismeretlen állatról, de evolúciósan denevérekből származik. Amennyiben ismerjük a természetben megtalálható, hasonló potenciállal rendelkező vírusokat azok részletes természetbeni tulajdonságaival, egyértelmű és hatásos megelőző lépésekkel elháríthatjuk, de legalább mérsékelhetjük emberi populációkban történő felbukkanásuk valószínúségét. Az ilyen kórokozók megismerését, a gyors és modern, továbbá hatékony vizsgálatukhoz szükséges innovatív kapacitásfejlesztést tűzte ki célul a VNL. A vizsgált állatcsoportokból kimutatott vagy felfedezett új vírusokat tovább vizsgálva a természetes folyamatok, transzmissziós tulajdonságok és innovatív kimutatási kapacitásfejlesztésen túl az eredmények más alapkutatási (pl. gyógyszerfejlesztés) vonalakon is közvetlenül hasznosulhatnak. A PTE SzKK Virológiai Kutatócsoport évtizedes tapasztalattal rendelkezik a természetben megtalálható zoonótikus vírusok mintázásában és komplex virológiai vizsgálatában.

\section{3-as és 4-es rizikócsoportba (Risk Group) tartozó vírusok (RG3 és RG4) vizsgálata BSL3 és BSL4 laboratóriumi körülmények között - alapkutatás}

Számos alapkutatási kérdés megválaszolására ad lehetőséget a laboratórium ezen kutatási tevékenysége. Ezek közül a legfontosabbak: a „virális patogenezis” vizsgálatok, új antivirális gyógyszerek kifejlesztése és azok múködési mechanizmusainak molekuláris szintű vizsgálata, valamint a vírusok teljes genom alapú vizsgálatai, bioinformatikai analízisek elvégzésével. A kutatásfejlesztés bázisát adó alapkutatások nélkül nincsen alkalmazott kutatás és kísérleti fejlesztés sem. A Virológiai Nemzeti Laboratórium feladatának tekinti, hogy a projektbe bevont tudományos partnerekkel, egyetemekkel, kutatóhelyekkel olyan magas színvonalú alapkutatási tevékenységet is végezzen, amelyre később az antivirális szerek fejlesztése vagy a vakcinafejlesztés is épülhet. Alapkutatási tevékenysége körében tervezi feltérképezni a vírusok molekuláris evolúcióját biológiai és bioinformatikai módszerekkel. Új vírusok kimutatására és molekuláris jellemzésére törekszik, továbbá vizsgálja a genom összetételének változásait is. A Centrum egyik fó célja új, állatok által hordozott vírusok azonosítása, monitorozása, betegség-ökológiai vizsgálata egyaránt.

\section{Nemzetközi szintü BSL-3 és BSL-4 oktató és képző centrum létrehozása}

Mivel a PTE SzKK laboratóriumban dolgozó munkatársak speciális nemzetközi tréningen szerezték meg a BSL szintnek megfelelő oktatást, így ezt a tudást integrálni képesek a hazai graduális/posztgraduális képzésbe is. Hazai BSL-3/4 tréningek tartása, oktatási szerep.

A személyi feltételek mellett egyedülálló laboratóriumi facilitási lehetőség is adott, hiszen a Kutatóközpont rendelkezik egy BSL-3 és BSL-4 gyakorló laboratóriummal is. Ennek használatával részt tudnak venni a hazai és nemzetközi laboratóriumi tréningeken. Ez a folyamat nagyban hozzásegítené hazánkat a nemzetköziesedéshez, elősegítené a kutatói mobilitást és a hazai kutatók nemzetközi elismertségének növelését.

\section{Utánpótlás-nevelés}

A kutatócsoport egyik erénye, hogy a részt vevő szenior kutatók mellett elsősorban fiatal, Pécsett végzett hallgatók alkotják a magját, kiegészülve külföldi PhDhallgatókkal. Ez a kapcsolatépítés szempontjából is elengedhetetlen, illetve nagy segítség az egyes nézőpontok különbözősége egy-egy téma elemzése során, hiszen így lehet kiemelkedő eredményeket elérni ezen a területen. Ezen folyamatot a jövőben is erősíteni szeretnék, hiszen a cél a kutatók megtartása! Továbbá fó 
cél még a hazai fiatal tehetségek összefogása, aktív részvétel a hazai kutatóképzésben, valamint, a kutatói mobilitás elősegítése, a hazai kutatók nemzetközi elismertségének növelése.

A Nemzeti Virológiai Laboratórium mint Regionális Kiválósági Centrum a hazai virológiai kutatások központi bázisaként, nemzetközi kapcsolatokra építve kívánja megteremteni a kohéziót a helyi kkv-k, a gyógyszerkutatással, diagnosztikummal és vakcinával foglalkozó nagyvállalatok, az állami szektor, valamint a tudományt képviselő kutatóhelyek és egyetemek között. A hazai $\mathrm{K}+\mathrm{F}+\mathrm{I}$ stratégia hangsúlyos pontja, hogy a kkv-k termelékenységét és innovációs képességét az egyetemközpontú innovációs ökoszisztéma kialakításán keresztül növelje, továbbá, hogy a hazai tulajdonú vállalkozások az innovációkon és az új technológiák alkalmazásán keresztül nemzetközileg is versenyképes, de elsősorban a hazai jólétet megalapozó szereplőkké váljanak.

\section{Multidiszciplinaritás}

Fontos kiemelni, hogy a projekt sikeres megvalósítása számos tudományterület együttmúködését feltételezi, a multidiszciplinaritás adja a Centrum egyik fó erősségét. Az orvostudományi kutatásokon túl a természettudományi (elsősorban biológia és kémia), vagy akár az állatorvostudományi kutatások területét is érinti, és magába foglalja elsősorban a virológia, de a mikrobiológia, az immunológia, a genetika és az epidemiológia szakterületeket. A kutatócsoport a diagnosztikai paletta fejlesztésével folyamatos szakmai kapcsolattartást épít ki a klinikumban dolgozó gyakorló orvosokkal, így lehetőség nyílik a vírusfertőzések klinikai jellemzőit is megfigyelni, nyomon követni.

\section{Záró gondolatok}

A virológusok, kutatók egységes álláspontja az, hogy sajnos az elkövetkezendő időszakban, évtizedekben a járványok korát fogjuk élni. Egyre gyakrabban lehet és kell számítani a mostani SARS-CoV-2-höz hasonló járványokra, amelyek akár az egész emberiséget is fenyegethetik. Amennyiben ezek az újonnan megjelenő kórokozók magas fertőzési képességgel rendelkeznek és/vagy teljesen új kórokozóként jelennek meg, amire sem speciális kezelés, terápia, sem pedig védőoltás nem áll rendelkezésre, akkor a fertőző ágenst mindenképpen a legmagasabb biológiai biztonsági szinten kell kezelni. A BSL-4-es biztonsági szintű virológiai kutatólaboratóriumok száma pedig európai viszonylatban is kevés, fóleg összehasonlítva a többi tudományterület laboratóriumi kapacitásával. A fertőző betegségek nemzetközi szintű leküzdésében nemzetközi összefogásra van szükség, amely határokon átnyúló projektek keretében valósítható meg. A VNL kutatói arra törekednek, hogy mind hazai, mind pedig nemzetközi szinten részt tudjanak venni hosszú távon is a fertőző betegségek elleni küzdelemben.

\section{Irodalomjegyzék}

van Doorn, H. R. (2014) Emerging infectious diseases. Medicine, Vol. 42. No. 1. pp. 60-63.

Marano, N., Arguin, P. M., \& Pappaioanou, M. (2007) Impact of Globalization and Animal Trade on Infectious Disease Ecology. Emerging Infectious Diseases, Vol. 13. No. 12. pp. 1807-1809.

Morens, D. M., Folkers, G. K., Fauci, A. S. (2004) The challenge of emerging and re-emerging infectious diseases. Nature, Vol. 430. No. 6996. pp. 242-249.

Wu, T., Perrings, Ch., Kinzig, A., Collins, J. P., Minteer, B. A., \& Daszak, P. (2017) Economic growth, urbanization, globalization, and the risks of emerging infectious diseases in China: A review. Ambio, Vol. 46. No. 1. pp. 18-29. 